\title{
IMMUNOLOGICAL HETEROGENEITY AMONG THE M- ASSOCIATED PROTEIN ANTIGENS OF GROUP-A STREPTOCOCCI
}

\author{
Jean P. Widdowson, W. R. Maxted and Alison M. Pinney \\ Cross-Infection Reference Laboratory, Central Public Health Laboratory, \\ Colindale Avenue, London NW9 5 HT
}

SEVERAL reports have suggested that the type-specific M proteins of group-A streptococci share antigenic determinants that cannot be separated from the type-specific material by various conventional protein-purification procedures (Beachey, Alberti and Stollerman, 1969; Pachman and Fox, 1970; Beachey and Stollerman, 1971; Widdowson, Maxted and Pinney, 1971a). However, Vosti, Johnson and Dillon (1971) succeeded in obtaining, by polyacrylamide-gel electrophoresis of acid-extracted type-12 M protein, a low-molecular-weight fraction that was type specific, and a higher-molecular-weight fraction with type-specific and non-specific determinants. More recently Cunningham and Beachey (1974) obtained the type-specific protein free from the non-specific material by controlled peptic digestion of the acid-extracted $\mathbf{M}$ protein of type 24. We found (see Maxted and Widdowson, 1972) that strains of certain group-A serotypes, e.g., 2, 22, 41, after treatment with streptococcal proteinase, yielded acid extracts devoid of type-specific $M$ protein but rich in the nonspecific antigen. Strains of other $M$ types, e.g., 1, 6, and 12 behaved differently when tested in this way, and gave extracts that were devoid of the type-specific and the non-specific factors.

Physico-chemical differences between the $M$ proteins of different serotypes are suggested by the presence of proteins of high molecular weight in the acidextracted and extracellular $M$ proteins of opacity-factor-positive, but not of most opacity-factor-negative serotypes (Widdowson et al., 1971b; Maxted and Widdowson, 1972; Pinney, 1974).

Antibody to the non-specific antigens associated with $M$ protein have been measured in human sera by various methods, including complement fixation (Widdowson et al., 1971a; Beachey, Ofek and Bisno, 1973), platelet aggregation (Beachey and Stollerman, 1971), haemagglutination (Vosti et al., 1971), and latex agglutination (Mihalcu, 1974). Titres are invariably higher in rheumatic fever than in nephritis (Widdowson et al., 1971a and 1974a; Beachey et al., 1973). The titres observed in uncomplicated throat infections are variable, and appear to depend on the nature of the infecting type of streptococcus (Widdowson et al., $1974 a$ and $b$ ). In throat infection with certain M types, in which 
opacity factor (OF) is absent, the titre is often high. In infections with other types, notably those in which OF is formed, and nephritogenic types whether OF positive or negative, titres are generally much lower.

Our previous work (Widdowson et al., 1971a) had suggested that certain human sera contained antibody to an acid-extracted trypsin-sensitive antigen or antigens which we called M-associated protein (MAP). Complementfixation tests with a limited number of sera showed that the antigen was present to a similar extent in the $0.2 \mathrm{M} \mathrm{HCl}$ extracts of all $\mathrm{M}$-positive group-A streptococci tested, regardless of serotype.

The purpose of the present investigation was to explore the antigenic differences between the non-specific $\mathbf{M}$-associated protein antigens of different serotypes by comparing their ability to combine and fix complement with human anti-MAP antibody. These studies have revealed interesting differences between MAP antigens, and have shown that this heterogeneity is reflected in the immunological response of patients to different infecting serotypes.

\section{MATERIALS AND METHODS}

\section{Streptococci}

A list of the stock laboratory cultures used in initial screening experiments is given in table I. Paired M-positive and M-negative variants (see Widdowson, Maxted and Grant, 1970) were used in some experiments, and M-positive strains of type 1 (SF130/13), type 2 (SF59), type 5 (T5B/PS), type 6 (S43/78), type 12 (1130), type 22 (3116), type 30 (Quinn), type $41(55 / 138)$, and type 49 (1544) were used in the preparation of acid extracts and partially purified M proteins.

\section{Growth media}

Todd-Hewitt Broth (Oxoid Ltd, London) with the addition of $1 \%(w / v)$ of Neopeptone (Difco Ltd, Detroit, Michigan, USA) was used unless otherwise stated.

\section{Typing sera}

Rabbit $\mathrm{M}$ and $\mathrm{T}$ antisera were prepared in the Streptococcus Reference Laboratory, Colindale.

\section{Human sera}

Sera from patients with rheumatic fever and acute glomerulonephritis were given by Dr Wafeya El Razaz, Pyramids Hospital, Cairo, Egypt, Dr Elizabeth V. Potter, Northwestern University, Chicago, USA, and Dr H. C. Dillon of Birmingham, Ala, USA. Sera from patients with uncomplicated streptococcal infections were from hospitals and public health laboratories in Britain. Normal sera were from laboratory workers. Sera were stored at $-20^{\circ} \mathrm{C}$.

\section{Typing of streptococci}

The streptococci were typed by the T-agglutination (Griffith, 1934) and M-precipitation methods. The latter test (Rotta et al., 1970) was performed in slides of $1 \%(\mathrm{w} / \mathrm{v})$ agarose gel with $0 \cdot 2 \mathrm{M}-\mathrm{HCl}$ extracts of streptococci (Lancefield, 1928) and absorbed type-specific antisera.

\section{Extraction and purification of $M$ proteins}

Hot-acid extracts were made with $0.2 \mathrm{M} \mathrm{HCl}$ by the method of Lancefield (1928). Purified $\mathrm{M}$ proteins were prepared from crude $0 \cdot 2 \mathrm{M}$-acid extracts by precipitation at $p \mathrm{H} 2$, ribonu- 
clease treatment, ammonium-sulphate fractionation (Lancefield and Perlmann, 1952), and chromatography on carboxymethyl cellulose (Fox and Wittner, 1965). All fractions were monitored for protein content and titre of type-specific $M$ antigen by methods already described (Widdowson et al., 1971a).

\section{Complement-fixation tests for MAP}

Method 1. A macro-complement-fixation test (Widdowson et al., 1971a), based on the method of Bradstreet and Taylor (1962), was used in the earlier part of the work to detect MAP antigens in extracts of streptococci of various serotypes, with the sera of various human donors as the source of antibody to MAP.

Method 2. This test, which was used later in more quantitative experiments, was based on the method of Levine (1967). Diluted antiserum $(0.5 \mathrm{ml})$ was mixed with $1.5 \mathrm{ml}$ of complement-fixation-test (CFT) diluent (Oxoid Ltd, London) and $0.5 \mathrm{ml}$ of guinea-pig complement (Burroughs Wellcome and Co., Beckenham), diluted to give $90 \%$ haemolysis, as determined by previous titration. A series of two-fold dilutions of the antigen under test was prepared, and $0.5 \mathrm{ml}$ of each dilution added to the reaction mixtures in spectrophotometer tubes. When the optimum dilution of anti-MAP serum was unknown, two-fold dilutions of serum were made and a checkerboard titration was performed with two-fold serial dilutions of antigen. Control tubes of antigen dilution + complement, antiserum dilution + complement, and complement alone in a total volume of $3 \mathrm{ml}$ were included in each test. After incubation at $2-4^{\circ} \mathrm{C}$ for $18 \mathrm{~h} 0.5 \mathrm{ml}$ of a suspension of sensitised sheep RBC (see Levine, 1964) was added to each tube and the tubes were incubated at $37^{\circ} \mathrm{C}$ for $60 \mathrm{~min}$. with occasional shaking. The tubes were cooled rapidly to $4^{\circ} \mathrm{C}$ and centrifuged at $1000 \mathrm{~g}$ for $5 \mathrm{~min}$. to sediment unlysed RBC. The optical density of the supernate was read at $413 \mathrm{~nm}$ on a Unicam SP600 spectrophotometer. The percentage of complement fixed in each reaction mixture was calculated from:

$$
\text { Reaction } \triangle E_{413} / \text { Control } E_{413} \times 100
$$

where reaction $\triangle E_{413}=$ the difference in $E_{413}$ between the test and the mean reading of the control tubes containing complement + antigen alone and complement + antiserum alone. The antigen and antibody controls did not give evidence of any independent pro- or anticomplementary activity. The results were plotted graphically as percentage fixation vs antigen concentration, expressed as $\mu \mathrm{g}$ of protein per reaction mixture.

Inhibition of complement fixation. The fixation of complement in a previously characterised immune system (antiserum + antigen A) may be inhibited by the addition of a hapten or closely related antigen (B), although antigen B is itself incapable of fixing complement with the antiserum under test (Wasserman and Levine, 1961). Dilutions of antiserum (in $0.5-\mathrm{ml}$ volumes) were mixed with $0.5 \mathrm{ml}$ of serial dilutions of antigen $\mathbf{B}+1.0 \mathrm{ml}$ of buffer and incubated at $60 \mathrm{~min}$. at $37^{\circ} \mathrm{C} ; 0.5 \mathrm{ml}$ of diluted complement was then added and $0.5 \mathrm{ml}$ of serial dilutions of antigen $\mathrm{A}$, and the tubes incubated at $2-4^{\circ} \mathrm{C}$ for $18 \mathrm{~h}$. Sensitised sheep $\mathrm{RBC}(0.5 \mathrm{ml})$ were added to each tube, and the tubes were incubated and read as described above (method 2). Tubes containing dilutions of antigen A, but no B, were included to obtain a reference curve of percentage fixation $v s$ concentration of antigen $A$ in the absence of blocking antigen. Control tubes of antigen (A and B separately) +complement (no antiserum) and antiserum + complement (no antigen) were included to check that there was no anti-complementary or pro-complementary activity. Control tubes containing dilutions of antigen B+antiserum, but no antigen $A$, were included to check that $B$ alone did not fix complement with the test serum.

Absorption of sera by streptococci. Streptococci were grown overnight at $37^{\circ} \mathrm{C}$ and the cells washed three times in saline $(\mathrm{NaCl} 0.85 \% \mathrm{w} / \mathrm{v})$. The deposit from $250 \mathrm{ml}$ of culture was used to absorb $5 \mathrm{ml}$ of a 1 in 10 dilution of antiserum. Complement $(0.5 \mathrm{ml}$ of undiluted guinea-pig serum) was added to all absorption mixtures to reduce anti-complementary activity. The mixtures were incubated at $37^{\circ} \mathrm{C}$ for $1 \mathrm{~h}$ and then centrifuged to remove streptococci. The supernate was heated at $56^{\circ} \mathrm{C}$ for $30 \mathrm{~min}$. to destroy complement. Serial 
dilutions of absorbed antiserum for complement-fixation tests were made from these initial 1 in 10 dilutions.

Tests for other streptococcal antibodies in human sera. Antistreptolysin-O and antideoxyribonuclease-B titres were determined by methods already described (Widdowson et al., 1974b); $50 \%$ values for the antibody titres of various groups of sera (= titre exceeded by $50 \%$ of the sera in the group) were calculated from cumulative-percentage curves. Bactericidal tests for type-specific antibody were performed as described by Maxted, Widdowson and Fraser (1973b).

\section{RESULTS \\ Fixation of complement by MAP antigens from various serotypes and the sera of two donors}

In our previous studies of the detection and purification of trypsin-sensitive MAP antigens from various group-A serotypes, the MAP content of test preparations was measured in the macro-complement-fixation test (method 1 ), with the sera of two laboratory workers (AP and DG) as the source of antibody to MAP. Complement was fixed by these sera to an approximately equal degree in the presence of optimum dilutions of acid extracts-or of partially purified $\mathbf{M}$ proteins-of streptococci of all $\mathbf{M}$ types tested, but showed no fixation in the presence of extracts of the corresponding M-negative variants when these were available (Widdowson et al., 1971a).

To find another laboratory worker with a useful serum titre of anti-MAP, we screened the sera of 10 persons, who did not give a history of recent streptococcal infection, in complement-fixation tests with a purified $M$ protein from a type-30 strain. This serotype is extremely rare and was used to rule out the possibility of fixation due to reaction between $M$ protein and type-specific antibody. Nine of these sera gave a negative result at a dilution of 1 in 10 and one $(\mathrm{CN})$ had a titre of $80-160$; but when this serum was tested with extracts of streptococci of certain other serotypes fixation did not occur.

Checkerboard titrations of sera AP and CN were then made against serial dilutions of acid extracts of a representative of each of the $39 \mathrm{M}$ types listed in table I. Serum AP at a dilution of 1 in 20 fixed complement with every extract at dilutions ranging from 1 in 80 to 1 in 640 depending on the extract. Serum $\mathrm{CN}$ at a dilution of 1 in 40 gave clearly positive results with extracts of 14 types (nos. 1, 3, 5, 6, 12, 14, 15, 17, 19, 24, 26, 30, 33, and 54) at dilutions corresponding to those reacting with serum AP; at optimum dilutions of all these extracts serum $C N$ had a titre of 80 and serum AP a titre of 40 . All the extracts that gave such reactions with serum $C N$ were of serotypes in which the OF reaction is negative (Maxted et al., 1973a) and only three of these have been reported to be associated with skin sepsis (see Wannamaker, 1970).

With extracts of five serotypes (nos. 41, 49, 52, 55, and 59) there was fixation with serum $\mathrm{CN}$ only at very low titre, or partial fixation in several wells, and the results obtained were variable in repeated tests. Two of these five serotypes (nos. 49 and 59) gave a positive OF reaction, but all have been associated with skin sepsis. There was no fixation with serum $\mathrm{CN}$ and extracts of the remaining 
20 serotypes; 18 of these gave a positive OF reaction and 11 have been associated with skin sepsis.

Thus strains reacting strongly with serum $\mathrm{CN}$ had a negative $\mathrm{OF}$ reaction and included members of $M$ types that have been associated with throat infection (e.g., types 1, 3, 5, 6, 12, 14, 19, 24, 30, see Rammelkamp, Denny and Wannamaker, 1952; Report, 1954; Denny and Houser, 1964; Parker, 1967; Widdowson et al., 1974a); only three of the types in this category (nos. 26, 33, and 54) have so far been recorded as causes of skin sepsis (see Wannamaker, 1970; Whittle et al., 1973). Weak and negative reactions with serum CN tended to be associated with a positive $\mathrm{OF}$ reaction or isolation from skin lesions, but the correlation was incomplete.

In a more limited series of tests with partially purified $\mathbf{M}$ proteins obtained by ammonium-sulphate fractionation and chromatography on carboxymethylcellulose columns, we found that serum AP fixed complement with the $\mathbf{M}$ proteins of all types tested (nos. 1, 2, 5, 6, 12, 22, 30, 41, and 49) but serum $\mathrm{CN}$ fixed complement only with the $\mathrm{M}$ proteins from the OF-negative types $1,5,6,12$, and 30 .

\section{Fixation of complement by MAP antigens of various serotypes and the sera of healthy persons}

In previous surveys of antibody to MAP in human sera we used purified $\mathbf{M}$ protein from M-type 30 as the test antigen (Widdowson et al., 1971a). Type 30 is an OF-negative "throat" serotype, and acid extracts or purified M protein of this type fixed complement equally well with the serum of AP or CN (see table I). We therefore re-examined, with extracts from other serotypes, sera from laboratory workers that we had previously found to fix complement with the optimum dilution of type-30 $\mathrm{M}$ protein. Extracts of M-negative variants of streptococci of types $2,6,12$, and 22 were used as negative controls. None of the sera fixed complement with these M-negative extracts, and we concluded that they were devoid of antibodies that fixed complement with group-carbohydrate antigen and other impurities in the crude acid extracts. The optimum dilutions of all antigen preparations from $\mathbf{M}$-positive strains had been determined in checkerboard titrations against serum AP. Serial dilutions of the test sera were then titrated against the optimum dilution of each extract. The different "spectra" of fixation of these 10 sera with the selected extracts are shown in table II. Sera no. 1 (serum AP in table 1) and no. 2 fixed complement to maximum titre with the extracts from all the M-positive strains tested. Sera nos. 3 and 4 were similar, but usually fixed complement poorly with extracts of the OF-positive serotypes. Sera nos. 6, 7, and 8, like serum CN (serum no. 5 in table II) failed to fix complement with extracts from OF-positive serotypes, gave variable results with extracts from OF-negative " skin "strains, but fixed well with the extracts of OF-negative "throat" serotypes. On the other hand, the results with serum no. 10 and to some extent serum no. 9 were the reverse of those obtained with sera nos. 1 to 8 , except that variation again occurred within the OF-negative " skin" serotype category. 


\section{TABLE I}

Differences between $M$ types in complement-fixation tests $(C F T)$ of $0 \cdot 2 \mathrm{M}-\mathrm{HCl}$ extracts with the serum of two human donors with antibody to MAP

\begin{tabular}{|c|c|c|c|c|c|}
\hline \multirow{3}{*}{$\begin{array}{l}\text { Strain number } \\
\text { or designation }\end{array}$} & \multirow{3}{*}{ M type } & \multicolumn{3}{|c|}{ Result of } & \multirow{3}{*}{$\begin{array}{l}\text { Reported association } \\
\text { with pyoderma } \S\end{array}$} \\
\hline & & \multicolumn{2}{|c|}{ CFT with serum } & \multirow[t]{2}{*}{$\begin{array}{l}\text { opacity-factor } \\
\text { (OF) test } \ddagger\end{array}$} & \\
\hline & & $\mathrm{AP}^{*}$ & $\mathrm{CN} \dagger$ & & \\
\hline $\begin{array}{l}\text { SF130/13 } \\
\text { B930/24 } \\
\text { T5B/PS } \\
\text { S43/78 } \\
\text { R53/1077 } \\
\text { Lowe } \\
\text { T15/32/1 } \\
\mathrm{J} 17 \mathrm{E} / 19 \\
\mathrm{~J} 17 \mathrm{D} / 50 \\
\mathrm{C} 98 / 97 \\
\mathrm{~J} 17 \mathrm{~F} / 51 \\
\mathrm{D} 24 / 26 \\
\text { C107/24/6 } \\
\text { R66/3443 }\end{array}$ & $\begin{array}{r}1 \\
3 \\
5 \\
6 \\
12 \\
14 \\
15 \\
17 \\
19 \\
24 \\
26 \\
30 \\
33 \\
54\end{array}$ & $\begin{array}{l}+ \\
+ \\
+ \\
+ \\
+ \\
+ \\
+ \\
+ \\
+ \\
+ \\
+ \\
+ \\
+ \\
+\end{array}$ & $\begin{array}{l}+ \\
+ \\
+ \\
+ \\
+ \\
+ \\
+ \\
+ \\
+ \\
+ \\
+ \\
+ \\
+ \\
+\end{array}$ & $\begin{array}{l}= \\
= \\
= \\
= \\
= \\
= \\
= \\
= \\
= \\
=\end{array}$ & $\begin{array}{c}\text { None } \\
\text { None } \\
\text { None } \\
\text { None } \\
\text { None } \\
\text { None } \\
\text { None } \\
\text { None } \\
\text { None } \\
\text { None } \\
5 \\
\text { None } \\
2 \\
2\end{array}$ \\
\hline $\begin{array}{l}\mathrm{C} 101 / 21 / 2 \\
\mathrm{~B} 737 / 34 / 3 \\
\mathrm{R} 66 / 1094 \\
\mathrm{R} 65 / 4127 \\
\mathrm{R} 68 / 2991\end{array}$ & $\begin{array}{l}41 \\
49 \\
52 \\
55 \\
59\end{array}$ & $\begin{array}{l}+ \\
+ \\
+ \\
+ \\
+\end{array}$ & $\begin{array}{l} \pm \\
\pm \\
\pm \\
\pm \\
\pm\end{array}$ & $\begin{array}{l} \pm \\
\bar{t}\end{array}$ & $\begin{array}{l}2 \\
2 \\
2 \\
2 \\
6\end{array}$ \\
\hline $\begin{array}{l}\mathrm{T} 2 / 44 / \mathrm{Rb} 4 \\
1000 \mathrm{~S} \\
\text { SS241 } \\
\text { T9/101/4 } \\
\text { T11/54/8 } \\
\text { SS31 } \\
\text { J17S } \\
\text { T22/83/2 } \\
\text { Mathew PHZ } \\
\text { Small } \\
\text { R403/48/1 } \\
\text { R67/3890 } \\
\text { R67/3884 } \\
\text { R69/2709 } \\
\text { R69/2714 } \\
\text { R66/3489 } \\
\text { SF2 }\end{array}$ & $\begin{array}{l}2 \text { (T2) } \\
2 \text { (T8/25/Imp. 19) } \\
4 \\
9 \\
11 \\
13 \\
18 \\
22 \\
25 \\
28 \mathrm{R} \\
48 \\
57 \\
58 \\
60 \\
61 \\
62 \\
63\end{array}$ & $\begin{array}{l}+ \\
+ \\
+ \\
+ \\
+ \\
+ \\
+ \\
+ \\
+ \\
+ \\
+ \\
+ \\
+ \\
+ \\
+ \\
+ \\
+\end{array}$ & $\begin{array}{l}\overline{-} \\
= \\
= \\
= \\
= \\
= \\
= \\
= \\
= \\
= \\
=\end{array}$ & $\begin{array}{l}+ \\
+ \\
+ \\
+ \\
+ \\
+ \\
+ \\
+ \\
+ \\
+ \\
+ \\
+ \\
+\end{array}$ & $\begin{array}{l}\text { None } \\
1 \\
\text { None } \\
\text { None } \\
\text { None } \\
2 \\
\text { None } \\
\text { None } \\
2 \\
\text { None } \\
\text { None } \\
2 \\
7 \\
3 \text { and } 6 \\
6 \\
\text { None } \\
4\end{array}$ \\
\hline $\begin{array}{l}\text { Provisional } \\
\text { M-types }\end{array}$ & $\left\{\begin{array}{l}\text { “3354" } " 3875 ” \\
\text { "PS346” }\end{array}\right.$ & $\begin{array}{l}+ \\
+ \\
+\end{array}$ & $\bar{z}$ & $\begin{array}{l}+ \\
+ \\
+\end{array}$ & $\begin{array}{l}4 \\
4 \\
4\end{array}$ \\
\hline
\end{tabular}

$+=$ Positive result; $-=$ negative result.

* Serum AP tested at a dilution 1 in 20 against serial dilutions of the acid extracts. Titre of serum AP was 40.

$\dagger$ Serum $C N$ tested at a dilution of 1 in $\mathbf{4 0}$ against serial dilutions of the acid extracts. Titre of serum $C N$ was 80 .

$\mp$ See Maxted and Widdowson (1972).

$\$$ References: $1=$ Dillon, Reeves and Maxted (1968); $2=$ Wannamaker (1970); $3=$ BergnerRabinowitz et al. (1971); $4=$ Maxted et al. (1973a); $5=$ Whittle et al. (1973); $6=$ Dillon and Dillon (1974); 7 = Parker et al. (1968). 
TABLE II

Complement-fixation tests on the sera of 10 laboratory workers with $0 \cdot 2 \mathrm{M}-\mathrm{HCl}$ extracts from different serotypes of group-A streptococci

\begin{tabular}{|c|c|c|c|c|c|c|c|c|c|c|c|}
\hline \multirow{2}{*}{$\begin{array}{l}0 \cdot 2 \mathrm{M}-\mathrm{HCl} \\
\text { extract of } \\
\text { streptococci } \\
\text { of M-type }\end{array}$} & \multirow{2}{*}{$\begin{array}{l}\text { Category } \\
\text { of type }\end{array}$} & \multicolumn{10}{|c|}{ Relative strength of reaction * with the stated extract at optimum dilution and serum no. $\dagger$} \\
\hline & & $\begin{array}{c}1 \\
(20-40) \ddagger\end{array}$ & $\begin{array}{c}2 \\
(160)\end{array}$ & $\begin{array}{c}3 \\
(80)\end{array}$ & $\begin{array}{c}4 \\
(160)\end{array}$ & $\begin{array}{c}5 \\
(80)\end{array}$ & $(80-160)$ & $\begin{array}{c}7 \\
(80)\end{array}$ & $\begin{array}{c}8 \\
(40-80)\end{array}$ & $\begin{array}{c}9 \\
(80-160)\end{array}$ & $\frac{10}{(80-160)}$ \\
\hline $\begin{array}{r}1 \\
5 \\
6 \\
12 \\
30\end{array}$ & OF -ve "throat" & $\begin{array}{l}++ \\
++ \\
++ \\
++ \\
++\end{array}$ & $\begin{array}{l}++ \\
++ \\
++ \\
++ \\
++\end{array}$ & $\begin{array}{l}++ \\
++ \\
++ \\
++ \\
++\end{array}$ & $\begin{array}{l}++ \\
++ \\
++ \\
++ \\
++\end{array}$ & $\begin{array}{l}++ \\
++ \\
++ \\
++ \\
++\end{array}$ & $\begin{array}{l}++ \\
++ \\
++ \\
\cdots+ \\
++\end{array}$ & $\begin{array}{l}++ \\
++ \\
++ \\
\ldots+ \\
++\end{array}$ & $\begin{array}{l}++ \\
++ \\
++ \\
++ \\
++\end{array}$ & $\begin{array}{l}+ \\
+ \\
+ \\
+\end{array}$ & $\begin{array}{l}z \\
\bar{z}\end{array}$ \\
\hline $\begin{array}{l}33 \\
41 \\
52 \\
55\end{array}$ & OF -ve "skin" & $\begin{array}{l}++ \\
++ \\
++ \\
++\end{array}$ & $\begin{array}{l}++ \\
++ \\
++ \\
++\end{array}$ & $\begin{array}{l}++ \\
++ \\
++ \\
++\end{array}$ & $\begin{array}{c}++ \\
+ \\
+ \\
+\end{array}$ & $\begin{array}{r}+\frac{+}{+} \\
\pm\end{array}$ & $\begin{array}{l}+ \pm \\
\ldots \\
\pm\end{array}$ & $\begin{array}{r}++ \\
++ \\
\cdots \\
\pm\end{array}$ & $\begin{array}{c}+ \pm \\
\pm \\
\pm\end{array}$ & $\begin{array}{r}++ \\
++ \\
\cdots \\
+\end{array}$ & $\begin{array}{l}++ \\
++ \\
-+\end{array}$ \\
\hline $22(\mathrm{~T} 2)$ & OF + ve " throat" & $\begin{array}{l}++ \\
++\end{array}$ & $\begin{array}{l}++ \\
++\end{array}$ & \pm & ++ & $\overline{-}$ & $=$ & $=$ & $=$ & $\begin{array}{l}++ \\
++\end{array}$ & ++ \\
\hline 22 & OF + ve "skin" & ++ & ++ & + & $\cdots$ & - & - & $\cdots$ & - & $\cdots$ & $\cdots$ \\
\hline "PS346"§ & & $\stackrel{++}{++}$ & $\stackrel{++}{++}$ & $\mp$ & + & $=$ & $\bar{z}$ & $=$ & $\bar{z}$ & ++ & $\begin{array}{l}++ \\
++\end{array}$ \\
\hline
\end{tabular}

$++=$ Maximum fixation titre of serum under test; $+=$ fixation titre less than maximum by one two-fold dilution or partial fixation in some wells; $+=$ slight fixation: $-=$ fixation titre $<10 ; \cdots=$ not tested.

$\dagger$ Serum 1 was from donor AP in table I; serum 5 was from donor $C N$ in table $I$.

Maximum titre.

8 Provisional $M$ type.

\section{Fixation of complement with antigens from two different serotypes and} sera from patients suffering from recent streptococcal infection

The complement-fixation titres of sera from groups of patients suffering from acute rheumatic fever, acute glomerulonephritis, or uncomplicated streptococcal sore throat, and sera from normal persons, were measured by method 1 with predetermined optimum dilutions of a purified $M$ protein from an M-type-30 strain (OF negative) and an acid extract of an M-positive, OFpositive type-22 strain. An acid extract of an M-negative variant of the type-22 strain was used as a negative control. None of the sera tested fixed complement with this M-negative extract. In some tests, antigens from other OF-positive serotypes were also used to confirm the results obtained with type-22 antigen. The possibility of fixation due to type-22 type-specific antibody could not be overlooked because M22 is not an uncommon type (Parker, 1967; Köhler, 1974). However, a group of 10 persons who had evidence of type-specific antibody to type 22 by the indirect bactericidal test (Maxted and Valkenburg, 1969 ) and the anti-OF test (Maxted, Widdowson and Fraser, 1973b) all had titres of $<10$ in anti-MAP tests, and showed no complement fixation with the dilution of type-22 antigen used, suggesting that the test was too insensitive to detect low levels of type-specific antibody in human sera.

Table III shows the results of the anti-MAP titres expressed as $50 \%$ values (see Methods) for the various groups of sera. Among patients for whom the infecting serotype was known, a comparison of the CFT titres obtained with test antigens from an OF-positive and an OF-negative $M$ type revealed striking 
TABLE III

Comparison of the ability of extracts from an OF-positive and an OF-negative streptococcus to fix complement with the sera of groups of patients with recent streptococcal infection*

\begin{tabular}{|c|c|c|c|c|c|c|c|}
\hline \multirow{2}{*}{$\begin{array}{l}\text { Serum from } \\
\text { patients in } \\
\text { clinical } \\
\text { category }\end{array}$} & \multirow{2}{*}{$\begin{array}{l}\text { Number of } \\
\text { sera tested }\end{array}$} & \multirow{2}{*}{$\begin{array}{l}\mathbf{M} \text { type of } \\
\text { infecting strain }\end{array}$} & \multirow{2}{*}{$\begin{array}{l}\text { OF reaction of } \\
\text { infocting strain }\end{array}$} & \multirow{2}{*}{$\begin{array}{l}\text { Site of } \\
\text { primary } \\
\text { infection }\end{array}$} & \multicolumn{2}{|c|}{$\begin{array}{l}50 \% \text { Values of CFT titres } \\
\text { for groups of sera tested } \\
\text { with M protein } \dagger \text { from }\end{array}$} & \multirow{2}{*}{$\begin{array}{c}\text { Ratio of } 50 \% \text { values } \\
\text { OF - ve/OF + ve test } \\
\text { antigens }\end{array}$} \\
\hline & & & & & $\begin{array}{l}\text { OF-negative } \\
\text { type (M 30) }\end{array}$ & $\begin{array}{l}\text { OF-positive } \\
\text { type (M22) }\end{array}$ & \\
\hline $\begin{array}{l}\text { Rheumatic fever (Egypt) } \\
\text { Rheumatic fever }\end{array}$ & $\begin{array}{l}47 \\
20\end{array}$ & $\begin{array}{l}\text { Unknown } \\
\text { Unknown }\end{array}$ & $\begin{array}{l}\text { Unknown } \\
\text { Unknown }\end{array}$ & $\begin{array}{l}\text { Throat } \\
\text { Unknown }\end{array}$ & $\begin{array}{r}90 \\
100\end{array}$ & $\begin{array}{l}20 \\
25\end{array}$ & $\begin{array}{l}4 \cdot 5 \\
4 \cdot 0\end{array}$ \\
\hline $\begin{array}{l}\text { Sore throat } \\
\text { Acute nephritis } \\
\text { Acute nephritis } \\
\text { Acute nephritis } \\
\text { Impetigo with or without }\end{array}$ & $\begin{array}{l}50 \\
10 \\
20 \\
10 \\
12\end{array}$ & $\begin{array}{r}5 \\
57 \\
55 \\
60 \\
2\end{array}$ & $\begin{array}{l}\text { Negative } \\
\text { Negative } \\
\text { Negative } \\
\text { Positive } \\
\text { Positive }\end{array}$ & $\begin{array}{l}\text { Throat } \\
\text { Skin } \\
\text { Skin } \\
\text { Skin } \\
\text { Skin }\end{array}$ & $\begin{array}{r}250 \\
36 \\
30 \\
12 \\
12\end{array}$ & $\begin{array}{r}32 \\
6 \\
10 \\
8 \\
12\end{array}$ & $\begin{array}{l}7 \cdot 8 \\
6 \cdot 0 \\
3 \cdot 0 \\
1 \cdot 5 \\
1 \cdot 0\end{array}$ \\
\hline $\begin{array}{l}\text { acute nephritis } \\
\text { Sore throat } \\
\text { Normal adults }\end{array}$ & $\begin{array}{l}10 \\
92\end{array}$ & $\begin{array}{c}(18 / 25 / 22 \\
22 \\
\text { None }\end{array}$ & $\begin{array}{l}\text { Positive } \\
\text { None }\end{array}$ & $\begin{array}{l}\text { Throat } \\
\text { None }\end{array}$ & $\begin{array}{r}10 \\
8\end{array}$ & $\begin{array}{r}10 \\
3\end{array}$ & $\begin{array}{l}1.0 \\
2 \cdot 3\end{array}$ \\
\hline
\end{tabular}

* All patients had evidence of recent streptococcal infection by virtue of an ASO titre $>200$, an anti-DNAase B titre $>250$ or both.

+ See text.

Sera in this group were selected because they had anti-MAP titres of $>80$ in our initial screening test with an OF-negative test antigen, hence the artificially high $50 \%$ value of 250 .

differences, which seemed to depend on whether the infecting serotype was OF positive or OF negative. In infections caused by OF-positive serotypes, complement-fixation titres were generally low and very similar, irrespective of the antigen used in the test; and ratios of $50 \%$ values of fixation titres with OFnegative / OF-positive test antigens were approximately equal to 1 . However, sera from patients with infection known to be caused by OF-negative serotypes, or sera from patients suffering from rheumatic fever showed large differences in their CFT titres with different antigens. Titres were always much higher with the type-30 (OF-negative) test antigen than with the antigen from the OF-positive serotype. This difference was greatest in a collection of sera from patients with throat infection caused by an M-type-5 strain, where the $50 \%$ value of the CFT titres was eight times greater with the type-30 than with the type-22 test antigen. Normal adults had generally low CFT titres $(50 \%$ value $=8)$ when tested with type-30 antigen, and even lower titres $(50 \%$ value $=3$ ) when tested with an antigen from an OF-positive serotype.

\section{Anti-MAP titres in paired sera from patients suffering from uncomplicated throat infection with an OF-negative serotype}

Paired sera, the first taken at the onset of symptoms and the second 4 weeks later, were obtained from 15 patients with M-type- 5 throat infections, and tested in a complement-fixation test against optimum dilutions of type-30 $\mathrm{M}$ protein (OF negative) and acid extracts of $M$-positive and $M$-negative variants of a type-22 strain (OF positive). None of the sera fixed complement with the M-negative extract. The sera taken at the onset of sore throat had similar titres with the antigens from both the $\mathrm{M}$-positive strains. The $50 \%$ value with the type- 30 antigen was 35 , compared with 25 for the antigen from the type-22 
TABLE IV

Effect of absorption with streptococci of various types on the complement-fixation titre of the sera of two donors

\begin{tabular}{|c|c|c|c|c|c|}
\hline \multirow{3}{*}{$\begin{array}{l}\text { Type of absorbing } \\
\text { suspension }\end{array}$} & \multirow{3}{*}{$\begin{array}{l}\text { OF reaction } \\
\text { of absorbing } \\
\text { strain } \dagger\end{array}$} & \multicolumn{4}{|c|}{$\begin{array}{l}\text { Relative strength of reaction* after absorption } \\
\text { of serum no. }\end{array}$} \\
\hline & & \multicolumn{3}{|c|}{$\begin{array}{l}2(160) \ddagger \\
\text { when tested with } 0 \cdot 2 \mathrm{M}-\mathrm{HCl} \\
\text { extracts of }\end{array}$} & \multirow{2}{*}{$\begin{array}{c}5(80)_{\ddagger}^{\ddagger} \\
\text { when tested with } \\
0 \cdot 2 \mathrm{M}-\mathrm{HCl} \text { extracts } \\
\text { of OF - ve throat } \\
\text { strains } \S\end{array}$} \\
\hline & & $\begin{array}{l}\text { OF +ve } \\
\text { strains } \S\end{array}$ & $\begin{array}{l}\text { OF -ve } \\
\text { skin } \\
\text { strains } \S\end{array}$ & $\begin{array}{l}\text { OF -ve } \\
\text { throat } \\
\text { strains } \S\end{array}$ & \\
\hline \multicolumn{2}{|c|}{$M$-positive strains of type } & - & - & 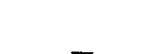 & \\
\hline $\begin{array}{l}2 \\
4\end{array}$ & $\begin{array}{l}+ \\
+\end{array}$ & $\overline{-}$ & $\bar{z}$ & $\overline{-}$ & $\overline{-}$ \\
\hline 22 & + & - & - & - & - \\
\hline 49 & + & - & - & - & \pm \\
\hline 12 & - & - & - & - & - \\
\hline 6 & - & + & + & + & + \\
\hline 55 & - & + & + & + & - \\
\hline \multicolumn{2}{|c|}{$M$-negative variants of type } & + & + & + & + \\
\hline $\begin{array}{c}\text { M-negatlve varlants } \\
2 \\
4 \\
6 \\
12 \\
22 \\
49\end{array}$ & $\begin{array}{c}\text { type } \\
(+) \\
(+) \\
- \\
(+) \\
(+)\end{array}$ & $\begin{array}{c}++ \\
<++ \\
t \\
++ \\
++ \\
+\end{array}$ & $\begin{array}{c}++ \\
<++ \\
\pm \\
++ \\
++ \\
+\end{array}$ & $\begin{array}{c}++ \\
<++>+ \\
\pm \\
++ \\
++ \\
+\end{array}$ & $\begin{array}{c}++ \\
<+>+ \\
\pm \\
++ \\
++ \\
+\end{array}$ \\
\hline
\end{tabular}

* CFT: $++=$ maximum titre for serum $=$ no absorption; $+=2$-fold reduction of titre; $\pm=4$-fold reduction of titre; $-=$ no fixation $=$ complete absorption.

$\dagger$ OF reaction: $+=$ opacity-factor-positive serotype; $-=$ opacity-factor-negative serotype; $(+)=$ M-negative variant of an OF-positive serotype: supernate OF negative but cells retaining the opacity factor.

$\ddagger$ In parenthesis: maximum titre of serum before absorption. No fixation occurred with the unabsorbed serum no 5 and extracts of OF-positive strains. Fixation was poor with extracts of OFnegative skin strains.

$\S$ For details of strains see Table II.

strain. However, the sera taken 4 weeks after infection with the OF-negative serotype, type 5 , showed a rise in titre to a $50 \%$ value of 150 against the OFnegative test antigen, compared with only 37 for the antigen from the OFpositive strain.

\section{Absorption studies}

We selected sera from two laboratory workers (nos. 2 and 5; see table II) for study of the removal of anti-MAP antibody by absorption with washed cells of streptococci of various serotypes.

Serum from donor no. 2 fixed complement to a titre of 160 with all the MAP-antigen preparations tested, but serum from donor no. 5 showed no fixation with acid extracts, or partially purified $\mathbf{M}$ proteins, of OF-positive serotypes, and variable weak fixation with extracts of strains of types 41,49 , $52,55,57$, and 59. Serum from these two donors was absorbed, as described 
in Methods, with various washed suspensions of streptococci of different $\mathbf{M}$ types and then diluted. Dilutions of serum no. 2 were tested against a battery of acid extracts of strains of OF-positive and OF-negative serotypes. Dilutions of serum no. 5 were tested against extracts of the OF-negative throat serotypes only (see table IV). The optimum dilutions of the test antigens were predetermined in a checkerboard titration with an unabsorbed serum from donor no. 2 . The results (table IV) show clearly that suspensions of OF-positive, M-positive streptococci are capable of absorbing all anti-MAP antibody from serum no. 5, in spite of the inability of extracts of OF-positive streptococci to fix complement with this serum (see table II). Thus after absorption with M-positive strains of M-types 2, 4, and 22, neither serum no. 2 nor no. 5 would fix complement with any of the antigens tested, and a type- 49 strain removed all anti-MAP antibody from serum no. 2 and considerably reduced the titre of serum no. 5 . Absorption with cells of M-type 12 (OF negative) also reduced the anti-MAP titre of both sera with all the test antigens to $<10$. Absorption with streptococci of types 6,55 , or 30 gave less clear-cut results, because there was a tendency for these types to make the absorbed sera anti-complementary, but in general titres with all of the test antigens were at least halved.

Absorption with M-negative variants gave different results according to the serotype of the absorbing strain. Absorption with M-negative variants of types 2,12 , and 22 had no effect on the titre of the test sera against any of the test antigens, and an M-negative variant of a type- 4 strain produced only slight reduction in titre. However, absorption with M-negative variants of type 6 and 49 reduced the CFT titres of both sera, with most of the test antigens, at least two-fold.

\section{Quantitative studies of the inhibition of complement fixation}

A preliminary experiment with dilutions of serum from donor $\mathrm{CN}$ ( 1 in 25-1 in 200) and a type-30 purified M-protein preparation, showed that a complete fixation curve could be obtained by complement-fixation method 2 with a serum dilution of 1 in 50, and with dilutions of antigen in the range 1 in 250 to 1 in $8000(0.15 \mu \mathrm{g}-4.5 \mu \mathrm{g}$ of protein per reaction mixture) with maximum (about $90 \%$ ) fixation at about 1 in 1000 (approximately $1 \mu \mathrm{g}$ of protein per reaction mixture) (see fig. 1). Purified M proteins from other OFnegative serotypes e.g., types 5 and 6 , gave similar curves with the serum of donor $\mathrm{CN}$, which was devoid of type-specific antibody to any of these serotypes in the direct or indirect bactericidal test, indicating that the fixation was due to a common non-specific antigen. The serum of donor $\mathrm{CN}$ did not fix complement with acid extracts of OF-positive serotypes and some OF-negative skin strains by method 1 (see table II), and this lack of fixation was confirmed by method 2. However, absorption studies indicated that cell suspensions of OF-positive serotypes completely absorbed anti-MAP from the serum, indicating either that the antigen was destroyed or changed during extraction of OFpositive cells, or that, although antigen and antibody were able to combine, complement was not fixed. Extraction of streptococci of OF-positive serotypes 


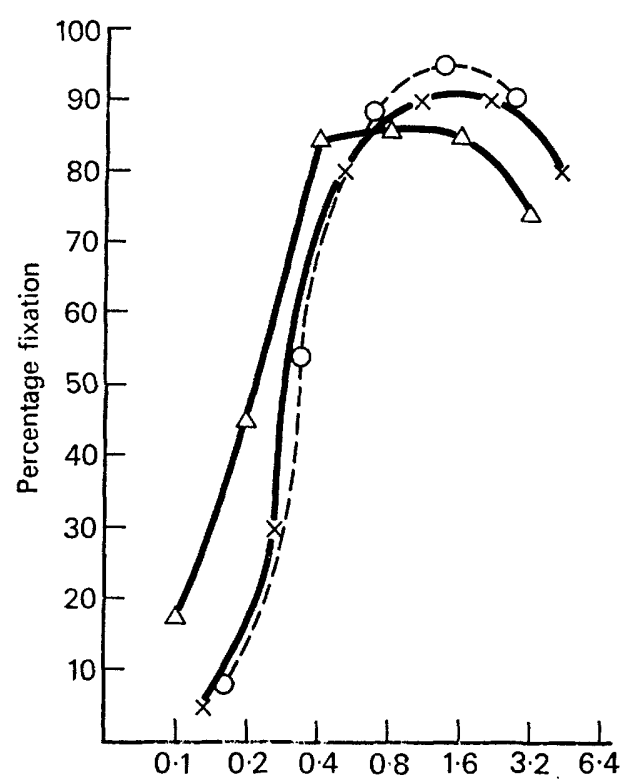

$M$ protein ( $\mu$ g per $3.5 \mathrm{ml}$ of reaction mixture)

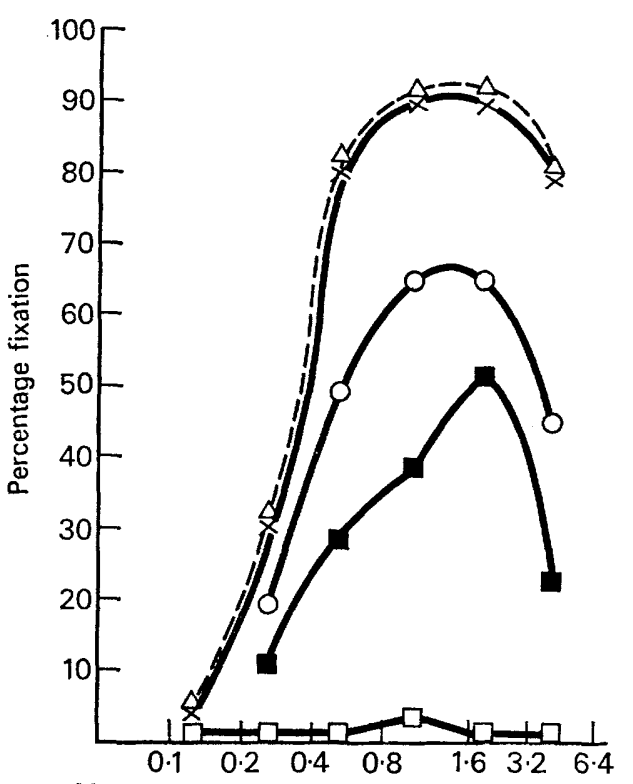

$\mathrm{M}$ protein ( $\mu \mathrm{g}$ per $3.5 \mathrm{ml}$. of reaction mixture)

FiG. 1.

Fig. 2.

Fig. 1.-Fixation of complement by a 1 in 50 dilution of serum from donor $\mathrm{CN}$ and purified $\mathrm{M}$ proteins from serotypes: M5 $(O)$, M6 $(\triangle)$, and M30 $(\times)$.

FIg. 2.-Inhibition of complement fixation with a 1 in 50 dilution of serum from donor $\mathrm{CN}$ and purified type-30 M protein by dilutions of crude acid extracts of: a type-55 M strain at 1 in 100 (D) and 1 in 400 dilution ( $(0)$, a type-22 $\mathrm{M}$ strain at 1 in 100 dilution $(O)$ and an M-negative variant of type 22 at 1 in 100 dilution $(\triangle)$. $(x)$ represents the fixation curve obtained in the absence of a blocking antigen.

with weaker acid $(0.067 \mathrm{M})$ or at a lower temperature $\left(60^{\circ} \mathrm{C}\right)$ also produced extracts that fixed complement with serum from donor AP but not from donor CN. However, fixation with a 1 in 50 dilution of serum $\mathrm{CN}$ and type-30 $\mathrm{M}$ protein could be eliminated or considerably reduced by previous incubation of the serum dilution with suitable dilutions of $0.2 \mathrm{M}-\mathrm{HCl}$ extract from OFpositive serotypes 2 and 22 or from OF-negative skin-type 55 (see fig. 2).

Incubation of this serum with $0.2 \mathrm{M}$-acid extracts of $\mathrm{M}$-negative variants of types 2 and 22 (which do not contain MAP antigen) had no effect on the fixation curve of serum CN with type-30 antigen. Fig. 2 shows the result of a typical blocking experiment, which suggests that although complement was not fixed with the serum of donor $\mathrm{CN}$ and antigens from OF-positive serotypes or some OF-negative skin strains, these antigens are able to combine with MAP antibody and prevent its reaction with other $M$ antigens that contain MAP.

\section{DISCUSSION}

The results of the experiments reported here confirm our observations (Widdowson et al., 1971a) and those of others (Vosti et al., 1971; Beachey and 
Stollerman, 1973) that the acid extracts of M-positive group-A streptococci contain cross-reactive antigenic material that is closely associated with the typespecific determinant of $\mathbf{M}$ protein. The exact nature of the material has not been established (see Beachey et al., 1973) but there is evidence that it is predominantly protein in nature (Vosti et al., 1971; Widdowson et al., 1971a; Cunningham and Beachey, 1974). Other investigators (Pachman and Fox, 1970) have suggested that the teichoic acid component present in purified $M$ proteins may contribute to the cross reactivity between $\mathbf{M}$ proteins of different serotypes. However, antibody to teichoic acid, which is detectable in fresh human serum by a passive haemagglutination technique, is destroyed by heating at $58^{\circ} \mathrm{C}$ or storage at $-20^{\circ} \mathrm{C}$ (Ne'eman and Ginsburg, 1972) and probably contributes little to the complement-fixation titres observed in tests with stored human sera and partially purified $\mathbf{M}$ proteins (see Beachey et al., 1973).

Our studies of the complement-fixation reaction between selected human sera and streptococcal extracts or partially purified $M$ proteins suggest that although the $\mathrm{M}$-associated antigens of certain serotypes are indistinguishable, there are differences between others that appear to divide the serotypes into three categories. Most of the OF-negative serotypes tested fall into one category, and have a common M-associated antigen or antigens, to which high titres of antibody are found in the sera of rheumatic-fever patients and patients recovering from uncomplicated respiratory-tract infections with certain OFnegative serotypes (see Widdowson et al., 1974a). Most of the OF-positive serotypes, including many that cause skin sepsis, appear to share another Massociated antigen, which is closely related but not identical with the antigen found in OF-negative serotypes. A third, less definite, category comprises $M$ types, e.g., nos. 41,52 , and 55, which are OF negative, and types 49 and 59 which are OF positive, all of which have been associated with skin sepsis. $M$ proteins of these serotypes gave variable results, and it is difficult to assign them to either of the first two categories.

The M-associated antigens of the different categories can be distinguished on the basis of the inability of the $M$ antigens from all OF-positive and certain OF-negative strains associated with skin infection to fix complement with the antibody of certain donors whose sera have high titres of anti-MAP against the M proteins of OF-negative " throat " serotypes. Conversely, certain other human sera contain antibody that will fix complement with the $M$ antigens of OF-positive, but not OF-negative serotypes. However, such sera are relatively rare and seldom have high antibody titres. Unlike many of the sera from patients recovering from infection with OF-negative serotypes, in which antiMAP titres often exceed 80 when measured with an OF-negative test antigen, the sera of patients recovering from infection with OF-positive serotypes generally have low titres of anti-MAP, irrespective of the category of MAP used in the complement-fixation test. This is in agreement with our previous finding that the M protein and the MAP of these serotypes are poorly antigenic (Widdowson et al., 1974a).

Despite this divergence of complement-fixing ability, the antibody to the 
M-associated antigens of OF-negative serotypes can be absorbed by cell suspensions of OF-positive serotypes. Moreover, acid extracts from OFpositive serotypes, and from some OF-negative skin strains, will block complement fixation by MAP antigens from OF-negative serotypes. This suggests that the antigens are very closely related and that antibody to one antigen has a demonstrable affinity for the other. However, this affinity seems insufficient for the formation of an antigen-antibody complex able to fix complement. The phenomenon of loose aggregate formation and poor complement fixation by low-affinity antibody has been demonstrated in other systems (Hill and Osler, 1955; Fauci, Frank and Johnson, 1970).

Whether stimulation by one category of $\mathrm{M}$-associated antigen will give rise to antibody capable of fixing complement with another is difficult to determine from the study of natural infections in man. Paired sera from patients with M-type-5 infections showed a sharp rise in complement-fixation titre when tested with an extract of an OF-negative streptococcus. The average rise in titre in test with an extract of an OF-positive streptococcus was smaller, but 5 of 15 patients in the group showed a two-fold or greater increase in titre between the first and second sera. Assuming that the patients had not had an infection with an OF-positive strain in the intervening 4 weeks, it seems possible that infection with M-type 5 had led to this increased ability to fix complement with an extract of an OF-positive serotype. Experiments now in progress show that guinea-pigs immunised with whole-cell vaccines of OFnegative serotypes first form antibody that fixes complement only with extracts of OF-negative serotypes; similarly, animals given vaccines of OF-positive serotypes first form antibody that reacts only with extracts of OF-positive serotypes. Several weeks later, however, sera from both groups of animals reacted with MAP antigens from a wider range of OF-negative and OF-positive serotypes.

The results of quantitative complement-fixation tests done by method 2 with purified $M$ antigens and a human serum (fig. 1) are in agreement with the observations of Beachey et al. (1974), and suggest that complement-fixation tests for the measurement of type-specific antibody to $M$ protein in human sera (Wittner and Fox, 1971) may be difficult to interpret unless carefully controlled. The human serum used in our experiments contained no type-specific antibody, detectable by the bactericidal test, against any of test serotypes, yet it fixed complement with the $\mathbf{M}$ proteins of three different $\mathbf{M}$ types that had been purified by methods similar to those used by Wittner and Fox (1971) (see Widdowson et al., 1971a). Similar results have been obtained with many other sera. Beachey et al., (1974) showed that the optimum concentration of type-30 $\mathrm{M}$ protein for the measurement of antibody to M-associated antigen was high $(100 \mu \mathrm{g} \mathrm{per} \mathrm{ml})$ in comparison with an optimum concentration of $5 \mu \mathrm{g}$ per $\mathrm{ml}$ for the measurement of type-specific antibody by their method. Basing our method on that of Wittner and Fox (1971), we found that as little as $1 \mu \mathrm{g}$ of the $M$ protein of types 5,6 , or 30 per $3.5 \mathrm{ml}$ of reaction mixture was optimum for complement fixation with anti-MAP sera devoid of type-specific antobody (see fig. 1). This antigen concentration is of the same order as that used by 
Wittner and Fox (1971) to measure type-specific antibody. The optimum concentration of our antigens required for measurement of type-specific antibody in rabbit sera was between four and eight times less for type-30 purified $\mathbf{M}$ protein, but for the $M$ proteins of types 5 and 6 , the maximum in the complementfixation curves for the measurement of either anti-MAP or anti-M occurred at approximately the same protein concentration of $1 \mu \mathrm{g}$ per $3.5 \mathrm{ml}$ of reaction mixture (Widdowson, unpublished).

Beachey and Stollerman (1973) suggested that the non-specific parts of $\mathbf{M}$ protein were masked in the intact cells of virulent M-positive streptococci by the type-specific moiety, but were exposed on the cell walls of M-negative variants. On the whole, our absorption studies do not confirm this (see table IV); M-positive variants of most of the serotypes that we tested absorbed anti-MAP more effectively than did their M-negative counterparts, and this was especially true of OF-positive serotypes. The paired M-positive and M-negative variants of our type- 6 strain were the main exception to this rule, and in this respect behaved similarly to the virulent and avirulent strains described by Beachey and Stollerman (1973).

\section{SUMMARY}

Different serotypes of group-A streptococci share common antigens that are closely associated with the type-specific determinant of $\mathbf{M}$ protein. By the use of selected human sera containing antibody to these $\mathbf{M}$-associated antigens, we have shown that group-A streptococci can be divided into three categories. The majority of the opacity-factor-negative respiratory serotypes possess a shared $\mathrm{M}$-associated antigen or antigens, to which high titres of antibody are common in patients with rheumatic fever, or patients recovering from upper respiratory infections with certain opacity-factor-negative serotypes. The antibody in these sera has a demonstrable but limited affinity for the $\mathbf{M}$-associated antigens of strains belonging to a second category of $M$ types, the majority of which are opacity-factor-positive serotypes of "throat" or "skin" origin. A third group, consisting mainly of opacity-factor-negative pyoderma serotypes, gave variable results and seemed to be intermediate between the other two categories. Complement-fixation-inhibition tests and absorption studies showed a marked degree of cross-reactivity between the M-associated antigens of the three categories.

We thank Dr Wafaya El Razaz, Dr T. Poon-King, Dr Elizabeth V. Potter, Dr I. Mohammed, Dr R. Cox, Dr H. C. Dillon, and Dr A. Colling for some of the sera used in this investigation. We are grateful to Miss Clare Notley and Miss M. Hardy for their expert assistance, and to Miss Cherry A. M. Fraser for the preparation of typing sera.

\section{REFERENCES}

Beachey, E. H., Alberti, H. and Stollerman, G. H. 1969. Delayed hypersensitivity to purified streptococcal $M$ protein in guinea-pigs and in man. J. Immunol., 102, 42.

BeaChEY, E. H., OfEK, I. AND Bisno, A. L. 1973. Studies of antibodies to non-type-specific antigens associated with streptococcal $M$ protein in the sera of patients with rheumatic fever. J. Immunol., 111, 1361. 
Beachey, E. H., Ofek, I., Cunningham, M. ANd Bisno, A. 1974. Evaluation of microcomplement fixation tests for antibodies against group $\mathrm{A}$ streptococcal $\mathbf{M}$ and $\mathbf{M -}$ associated antigens in rabbit and human sera. Appl. Microbiol., 27, 1.

Beachey, E. H. AND Stollerman, G. H. 1971. Toxic effects of streptococcal M protein on platelets and polymorphonuclear leukocytes in human blood. J. exp. Med., 134, 351 .

BeAChey, E. H. AND Stollerman, G. H. 1973. Mediation of cytotoxic effects of streptococcal $\mathrm{M}$ protein by non-type-specific antibody in human sera. J. clin. Invest., 52, 2563.

Bergner-Rabinowitz, S., Ofek, I., Davies, M. A. and Rabinowitz, K. 1971. Typespecific streptococcal antibodies in pyodermal nephritis. J. infect. Dis., 124, 488.

Bradstreet, C. M. P. and TayloR, C. E. D. 1962. Technique of complement-fixation test applicable to the diagnosis of virus diseases. Mon. Bull. Minist. Hlth, 21, 96.

Cunningham, M. W. AND Beachey, E. H. 1974. Peptic digestion of streptococcal M protein. I. Effect of digestion at suboptimal $p \mathrm{H}$ upon the biological and immunochemical properties of purified M protein extracts. Infect. Immun., 9, 244.

DENNY, F. W. JR AND Houser, H. B. 1964. Discusion of paper The epidemiology of primary and secondary rheumatic fever, by G. H. Stollerman, in The streptococcus, rheumatic fever and glomerulonephritis, edited by J. W. Uhr, Baltimore, p. 330.

Dillon, H. C. AND Dillon, M. S. A. 1974. New streptococcal serotypes causing pyoderma and acute glomerulonephritis, types 59,60 and 61. Infect. Immun., 9, 1070.

Dillon, H. C., Reeves, M. S. AND MAXTED, W. R. 1968. Acute glomerulonephritis following skin infection due to streptococci of M-type 2. Lancet, 1, 543.

FAUCI, A. S., Frank, M. M. AND Johnson, J. S. 1970. The relationship between antibody affinity and the efficiency of complement fixation. J. Immun., 105, 215.

FoX, E. N. AND WIrTNER, M. K. 1965. The multiple molecular structure of the M proteins of group A streptococci. Proc. natn. Acad. Sci., USA, 54, 1118.

Hill, B. M. AND OsLer, A. G. 1955. Kinetic studies of complement fixation. II. The role of the aggregating capacity of antibody and its heterogeneity. J. Immun., 75, 146.

Griffith, F. 1934. The serological classification of Streptococcus pyogenes. J. Hyg., Camb., 34, 542.

KöHLER, W. 1974. Results of the second international Streptococcus pyogenes type distribution survey. In Streptococcal disease and the community, Proc. 5th Int. Symp. on Streptococcus pyogenes, edited by M. J. Haverkorn, Amsterdam and New York, p. 10.

LANCEFIELD, R. C. 1928. The antigenic complex of Streptococcus haemolyticus. I. Demonstration of a type-specific substance in extracts of Streptococcus haemolyticus. J. exp. Med., 47, 91.

Lancefield, R. C. and Perlmann, G. E. 1952. Preparation and properties of type-specific $\mathrm{M}$ antigen isolated from a group A, type 1, haemolytic streptococcus. J. exp. Med., 96, 71.

Levine, L. 1967. Micro-complement fixation. In Handbook of experimental immunology, edited by D. M. Weir, Oxford and Edinburgh, p. 707.

MaXted, W. R. AND Valkenburg, H. A. 1969. Variation in the M antigen of group A streptococci. J. med. Microbiol., $2,199$.

MAXTED, W. R. AND WIDDOwson, J. P. 1972. The protein antigens of group A streptococci. In Streptococci and streptococcal diseases, edited by L. W. Wannamaker and J. M. Matsen, New York and London, p. 251.

MaXted, W. R., Widdowson, J. P. AND Fraser, C. A. M. 1973b. Antibody to streptococcal opacity factor in human sera. J. Hyg., Camb., 71, 35 .

Maxted, W. R., Widdowson, J. P., Fraser, C. A. M., Ball, L. C. and Bassett, D. C. J. 1973a. The use of the serum-opacity reaction in the typing of group A streptococci. J. med. Microbiol., 6, 83.

Minalcu, F. 1974. The application of the latex agglutination test to the study of antibodies to the $\mathrm{M}$ proteins of group A streptococci. In Streptococcal disease and the community, Proc. 5th Int. Symp. on Streptococcus pyogenes, edited by M. J. Haverkorn, Amsterdam and New York, p. 126. 
Ne'eman, N. AND Ginsburg, I. 1972. Red cell-sensitizing antigen of group A streptococci. III. Immunological and immunopathological properties. Israel J. med. Sci., 8, 1807.

Pachman, L. M. AND Fox, E. N. 1970. Cellular and antibody reactions to streptococcal M protein types 1, 3, 6 and 12. J. Immun., 105, 898.

PARKER, M. T. 1967. International survey of the distribution of serotypes of Streptococcus pyogenes (group A streptococci). Bull. Wld Hlth Org., 37, 513.

Parker, M. T., Bassett, D. C. J., Maxted, W. R. and Arneaud, J. D. 1968 . Acute glomerulonephritis in Trinidad: serological typing of group A streptococci. J. Hyg., Camb., 66, 657.

PInNey, A. M. 1974. Some type-associated characteristics of group A streptococci. In Streptococcal disease and the community, Proc. 5th Int. Symp. on Streptococcus pyogenes, edited by M. J. Haverkorn, Amsterdam and New York, p. 56.

REPORT. 1954. Serotypes of Streptococcus pyogenes. Their relative prevalence in England, Wales and Northern Ireland, 1952-53. Mon. Bull. Minist. Hith., 13, 171.

Rammelkamp, C. H., Denny, F. W. and Wannamaker, L. W. 1952. Studies on the epidemiology of rheumatic fever in the armed services. In Rheumatic fever, edited by L. Thomas, Minneapolis, p. 72.

Rotta, J., Krause, R. M., Lancefield, R. C., EVerly, W. and Lackland, H. 1970. New approaches for the laboratory recognition of $\mathrm{M}$ types of group A streptococci. $J$. exp. Med., 134, 1298.

Vosti, K. L., Johnson, R. H. AND DILlon, M. F. 1971. Further characterization of purified fractions of M-protein from a strain of group A type 12 streptococcus. J. Immun., $107,104$.

WANNAMAKER, L. W. 1970. Differences betwen streptococcal infections of the throat and of the skin. New Engl. J. Med., 282, 23, 78.

WASSERMAN, E. AND LEVINE, L. 1961. Quantitative micro-complement fixation and its use in the study of antigenic structure by specific antigen-antibody inhibition. J. Immun., 87, 290.

Whittle, H. C., Abdullahi, M. T., Fakunle, F., Parry, E. H. O. and Rajkovic, A. D. 1973. Scabies, pyoderma and nephritis in Zaria, Nigeria. A clinical and epidemiological study. Trans. R. Soc. trop. Med. Hyg., 67, 349.

Widdowson, J. P., MAXTED, W. R. AND GRANT, D. L. 1970. The production of opacity in serum by group A streptococci and its relationship with the presence of $M$ antigen. J. gen. Microbiol., 61, 343.

Widowson, J. P., Maxted, W. R. And Pinney, A. M. 1971a. An M-associated protein antigen (MAP) of group A streptococci. J. Hyg., Camb., 69, 553.

Widdowson, J. P., Maxted, W. R., Grant, D. L. AND PinNeY, A. M. 1971b. The relationship between $\mathrm{M}$ antigen and opacity factor in group A streptococci. J. gen. Microbiol., $65,69$.

Widdowson, J. P., Maxted, W. R., Newrick, C. AND Parkin, D. 1974b. An outbreak of streptococcal sore throat and rheumatic fever in a Royal Air Force training camp; significance of serum antibody to M-associated protein. J. Hyg., Camb., 72, 1.

Widdowson, J. P., MAXted, W. R., Notley, C. M. AND PINNeY, A. M. 1974a. The antibody response in man to infection with different serotypes of group A streptococci. $J$. med. Microbiol., 7, 483.

WitTNER, M. K. AND Fox, E. N. 1971. Micro-complement fixation assay for type-specific group A streptococcal antibody. Infect. Immun., 4, 441. 